\title{
Implementation of MEE (Medical, Education, Eco-Tourism): A Strategy For Collaborative Forest Management In Meru Betiri National Park, Indonesia
}

\author{
Andik Kurniawan*, Abdul Manan, Budi Santoso \\ Konservasi Alam Indonesia Lestari (KAIL), Jember, Indonesia
}

\begin{abstract}
Global issues of greenhouse effects include the depletion of the ozone layer and the increases ground surface temperature. Responses to these issues have been attempted to empower and enhance the role of community participation in sustainable and equitable forest resource management. Since 1993 Konservasi Alam Indonesia Lestari (KAIL) - an Indonesian NGO in Jember Regency, East Java- starts empowering the forest buffer community with MEE (Medical, Education, Ecotourism) site model. The purpose of this paper is to describe the model of MEE in empowering forest buffer communities, describe the ecological, economic and social impact of the model, and describe the collaborative forest management. The success of MEE site model reduces negative perceptions on communities that have less conservation awareness. Community-based forest resources management need to integrate ecological and economic value in achieving forest conservation and community's welfare.
\end{abstract}

Keywords: MEE (medical, education, eco-tourism), forest management, Meru Betiri National Park

\section{INTRODUCTION}

Forest resources of Indonesia are abundant with vast forest area approximately 120 million acres. The potential was believed to be a direct income for about $25 \%$ total of the Indonesian population that lived in and surround forest areas [1]. Forests also provide indirect benefits that often priceless, including function of water management systems to prevent flooding during the wet and drought season [2].

International community recognizes the existence of Indonesian forest resources as one of the most important parts to maintain the ecological balance of earth in cross-generation functions [3]. Indonesia forest functioned to absorb emissions of various gases and toxic pollutants [4] that cause increased greenhouse effect and depletion of the ozone layer. In the history, the forestry sector is always occupied a strategic role for various purposes, particularly for the fulfillment of achieving the welfare and prosperity of all community.

Ironically, forestry tends to always present a paradoxical reality. It is said that the renewable sector, the activities continues to be sustaineble. However, the fact is forestry activities on the

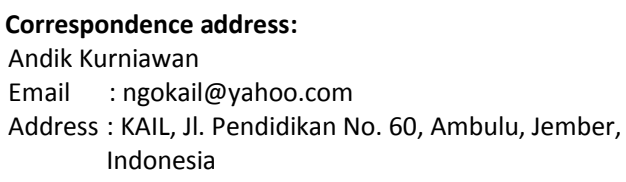

verge of destruction now [5]. The forestry industry in the downstream that ranging from plywood, sawmill, molding to furniture is in agony. Otherwise, forest management activities in the upstream through forest concessions are almost death. The hot issue that is spread in various circles did not mention the existence of state institutions in the forestry sector with all senior foresters. All components of forestry society that has concern the development is threatened with extinction.

At the global level contemporary issues, symptoms of greenhouse effect include the depletion of the ozone layer and the Earth's surface temperature getting more increases [1]. Climate anomalies such as changes in temperature and extreme seasons either in the tropics and the polar regions has led to the emergence of a various natural disasters. The most notable disaster is forest fires that led to the causes of enormous damage to forests. Yet for centuries, this changing climatic conditions prevailing in different regions of the world recently has never happened before.

In response to these issues, we attempt to empower and enhance the role of community participation in sustainable and equitable forest resource management. Thus, since 1993 Indonesian NGO Konservasi Alam Indonesia Lestari (KAIL) starts empowering the forest edge 
community with MEE (Medical, Education, Ecotourism) role model.

The first stage of this implementation model is Medical (planting of medicinal plants). This step is intended to preserve endemic biodiversity of Meru Betiri National Park, e.g. kluwek (Pangium edule), Kemiri (Alleurites mollucana), Joho lawe (Terminalia balerica) and Kedawung (Parkia roxburgi). Secondly, education about herbal cultivation efforts strived in the form of learning discourse for local community, especially educated inhabitants. So in the future they understand potential crops of Meru Betiri that contain high benefits such as medicinal content. Third, Ecotourism (nature tourism); optimize community empowerment after planting. Re-lush forests strived to provoke public interest either inside or outside the region to directly assess the diversity of medicinal plants and shrubs. This strategy is act as natural socialization and recreational [6] medium for anyone who wants to enjoy the beauty and coolness of nature. Therefore, we purpose this paper to describe the model of MEE in empowering forest edge communities, describe the ecological, economic and social impact of the model, and describe collaborative forest management that fair, conserve and sustainable.

\section{The Meru Betiri National park}

The Meru Betiri National Park (MBNP) is located in Banyuwangi and Jember Regency, East Java Province. The width of MBNP area reached 58 thousand hectares which divided into various zones, i.e. 27.915 ha core (special preservation) zone, 22.622 ha wilderness zone, 1.285 ha intensive use zones, 4.023 ha rehabilitation zone, and 2.155 ha special use zones. Core zone is an absolute protected area and there should be no human activity that alters the region, except those related to science, education, and research. MBNP is geographically located at 113038'38" - 113058'30" E and 8020'48" $8033^{\prime} 48$ " S. Topography of MBNP is generally hilly with elevation ranges from sea edge to a height of $1.223 \mathrm{~m}$ above sea level of Mount Betiri's Peak.

Meru Betiri forest areas are covered mainly by the tropical rain forests. It has some dominant plant species such as Bayur (Pterospermum javanicum), Bungur (Lagerstroemia speciosa), Glintungan (Bischoffia javanica), Segawe (Adenanthera microsperma), Aren (Arenga pinnata), Bendo (Artocarpus elasticus), Suren (Toona sureni), and Langsat (Lansium domesticum). Some plant species are endemic, including Rafflesia zollingeriana - a parasitic plant species on host plants Tetrastigma sp; and other typical plant species, Balanophora fungosa.

In the 58 thousand ha forest, there is also the vegetation of Bubat Bamboo (Bambusa sp), Wuluh Bamboo (Shizastychyum blumel), and Lamper Bamboo (Shizastychyum branchyladium). Other biodiversity are various types of rattan which is endemic in Meru Betiri, i.e. Manis Rattan (Daemonoropos melanocaetes), Slatung Rattan (Plectomocomia longistigma), and Warak Rattan (Plectomocomia elongate).

MBNP have several well known points of natural attractions, e.g. Sukamade and Bande Alit. Sukamade is a well-known turtle landing area and frequently visited by foreign tourists. Statistical data on MBNP visits showed that most tourists are attracted to visit the white sandy beaches in the national park, and less attracted in and around forest communities.

\section{The MEE Concept}

MEE (Medical, Education, and Ecotourism) is a model of collaborative forest management that emphasizes three basic principles, i.e. medical (cultivation of medicinal plants), education (learning media or research) and ecotourism (nature tourism).

\section{Medical (Cultivation of Medicinal Plant)}

We meant biodiversity conservation on native medicinal plants (endemic) in Meru Betiri. Medicinal plants are plants which part of the plant (roots, stems, bark, leaves, roots, fruit, seeds and sap) has medicinal properties and used as a raw material in the manufacture of modern or traditional medicine. Zuhud et al. [7] explained medicinal plants as entire species of medicinal plants that are known or believed to have medicinal properties. It grouped into traditional medicinal plants, modern herbs medicine, and the potential medicinal plants.

Meanwhile, Hadipoentyanti and Rostiana [8] stated medicinal plant is species that part or all parts of the natural plant exudates are used as a drug, substance or herb medicines. Similar to Gunarto [9], medicinal plants is one, some or all parts of the plant (leaves, flowers, roots, stems, rhizomes, tubers, seeds and sap) which contain the active compound that affect on health care and disease prevention.

\section{Education}

Ecotourism development should contain elements of education to change the attitudes or 
behavior of a person to have concern, responsibility and commitment to the environment conservation. Ecotourism development should also increase awareness and appreciation to nature, the values of the historical and cultural heritage, and provide additional value and knowledge for visitors, community and stakeholders. Ecotourism also acted as a medium of learning or research (nature laboratory) for communities around and away from the main forest, especially students. They can investigate drug content of the plant's parts (fruits, leaves, stems, bark to roots). Development of ecotourism product should fullfil these five criteria: (1) optimizing the uniqueness and distinctiveness of the area as a tourist attraction; (2) utilizing and optimizing the traditional knowledge which natural and cultural conservation-based and the additional values of daily lives of community; (3) optimizing the role of local communities as local interpreters of ecotourism products; (4) provide a qualified and valued experience to visitors; and (5) packed in the form of communicative and innovative delivery techniques.

\section{Ecotourism}

Ecotourism is an organized tourist activity in natural areas, such as national parks [10]. Ecotourism allows interaction and learning about biodiversity in national parks can last well and provide valuable experience for tourists. Ecotourism has the objective to improve the welfare of the forest's surround community. East Java is potential area for eco-tourism destination, because there are four national parks - Bromo Tengger Semeru, Baluran, Alas purwo, and Meru Betiri [2].

Implementation of community empowerment with MEE is an approach to capacity enhancement of farming as forest buffer (buffers-zone) by three elements; Medical, Educatian and Ecotourism. Approach toward this model responded to the level of concern for the forest resources ecosystem, but at the same time increased the community welfare [11]. MEE implementation approach is the integration of three main farmer mentoring objectives, i.e. ecological, economic and social objectives.

\section{Site model of MEE}

Implementation of MEE models in the initial period begin with creating MEE medicinal plants site model. Initial land used about seven forest rehabilitation zone of Meru Betiri in 5.470 ha area. Selected plants were the medicinal ones, such as Kluwek, Kedawung, Kemiri, etc. Realization of the MEE site model conducted with the following steps.

\section{Site Assesment}

Observation and recognition process was conducted to determine the ecological conditions and socio-cultural of forest buffer community. Close and comprehensive approach was made in implementing MEE. If the guide know the real condition of the forest, then the strategy of involving communities in forest management affect the improvement on the forest condition. Some basic ecological output that was expected on locations assessment process is geographic soil texture, diverse plants and animals. Direct observation showed that Meru Betiri forest is geographically hilly and wavy. Plant species in Meru Betiri forest divided into staple crops and intercropping plants (seasonal).

In socio-cultural context, the forest buffer community of Meru Betiri - especially in Jember Regency -consists of Andongrejo, Curahnongkoh, Sanenrejo and Wonoasri. Daily interactions of these groups are strongly affected by tradition of Madura [12]. With relatively limited educational background - the average education is elementary school graduate - almost total livelihoods of local communities depend on forest resources. Therefore, at a certain point, conflict frequently occurs with forest managers due to different attitude with community, similar to Borneo Community research [13]. For the community, forest is a gift of God and the creation is intended to be used for human survival. Otherwise, the State as emphasized the existence of the forest, even though the existence of communities around the forest has been there first before the State was established. This is what broke the way the community views forest differ with forest managers (Ministry of Forestry). For communities, forest should be open access, not close acces. The pattern of this point of view is attempted by NGOs KAIL with mentoring patterns of MEE strategy, where people could understand the functions of the forest and on the other hand the society also gets welfare for their life.

In addition, persona and administrative officer were identified by assessment performance development at rural authority level. Territorially, the management power on demographic interaction of community is the responsibility of the village leaders [12]. MEE 
implementation could run more effectively by cooperation pattern with the village government officials. KAIL also built communication patterns with village officials on running MEE program that could be especially beneficial for community, while in general village get revenue (income) - that if MEE zone achieved to be attraction for community to visit.

The site assessment process of MEE implement in one of Meru Betiri forest area. We develop partnership program with the support of VSO-Spark Netherlands that hold consistent in environment conservation, especially forest resources. Site assessment efforts were conducted to optimize the MEE zone that could provide mutual benefit.

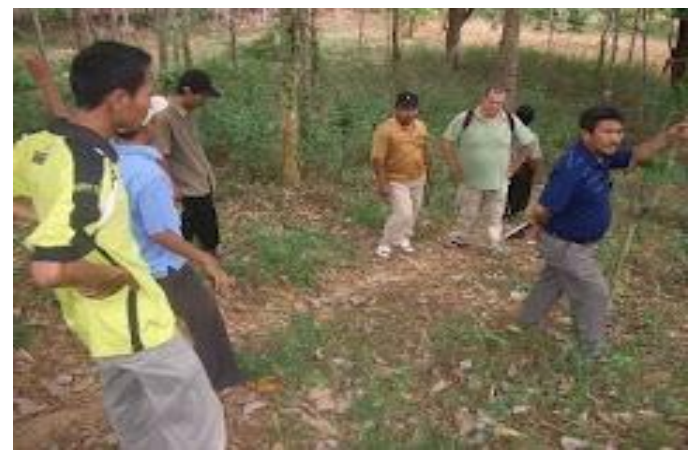

Figure 1. MEE Site Assesment by Mike and Stumpal (VSOSpark, Netherlands)

\section{Establishment of Institute Organization}

After the site assessment, KAIL performed an internal mentoring formation. The guide will be directed into facilitators of an integrated and sustainable community development. The next step is forming community groups that will be involved in MEE activities. Once the group is formed, the guide together with group members create consensus (agreements) that apply for groups, e.g. scheduling group meetings, selecting the main endemic plant species for forest, plant spacing to deposit due to the Joint Venture. Joint Venture income derived from savings of each member so that at any given moment will be used, such as to purchase fertilizer.

In the realization of the MEE region establishment, three groups were made with 43 members. Majority of the community members have black records on the use of forest resources. The selection of the communities group was based on the assumption that if the group of bromocorah - freebooters (timber and wildlife stealth) - is controlled, then MEE implementation will be realized.

\section{Primary Crop Planting}

After the mentoring process, primary crops that have been selected planted in accordance with the native plants of the area, i.e. Kedawung (Parkia roxburghii), Kluwek (Pangium edule), Trembesi (Enterolobium saman), Pule Pandak (Rauwolfia serpentina), Javanese Chili (Piper retrofractum), and Kemukus ( $P$. cubeba). As additional, primary crops was intercropped with medicinal plants [12], such as peanuts, corn, spices (ginger, turmeric, etc). The intercropping crops will be stopped if the primary plant has been enlarged, because intercropping crops is not classified as shade tolerant.

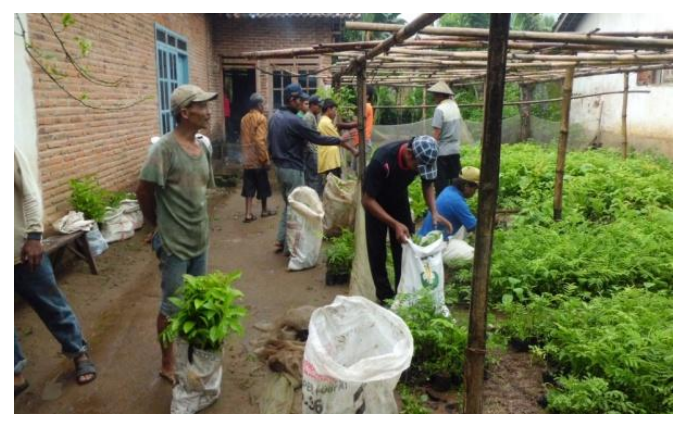

Figure 2. Plant Seedling by Community Groups and KAIL

\section{Improving the Quality of Human Resources}

Within the enrichment framework of perception, resident's activities are planning techniques, implementation, post-harvest handling, and marketing strategy. Capacity strengthening is needed to aware the community about the crucial of future forest resources, and at the same time maintains independent or selfhelp willingness. The existence of community groups who aware the importance of forest would lead to the coluntary rangers or keeper for the forest ecosystem. At the stage of community capacity building, the guide aware that community participation is the main pillars of success. Therefore, several activities should be done. First, we conducted a focus group discussion. This focus group discussion is directed to find solutions [14] against group's problems such as forestry technical issues (planting and caring) in accordance with the model of local wisdom. In addition, group discussions can be pursued as a means of control when a member violates the collective agreement.

The second is forestry cultivation training. Training activities of forestry plants pursued towards technical knowledge of modern planting as farmer's enrichment material. Third, we conducted benchmarking study. This activity is 
carried out in order to enrich the knowledge of farmers about other farmers outside their area. In addition, this step can be a medium to share their experiences related to advantages and disadvantages of forest conservation and community development. The site for the benchmark is Association of Metra Medica Malang, which has a specialist on medicinal plants (Medical).

\section{Creating and Developing of Productive Bussiness}

Productive activities directed to increase community incomes while waiting primary crops to bear fruit. Productive business is expected to sustain economic power of family. The type of activities is in the form of development of existing productive business or opens a new business. For women who succeeded in business is on the manufacture of medicinal products. Initially, we managed to set up a group of Family Medicinal Plant (TOGA - Tanaman Obat Keluarga) named SUMBER WARAS which is located in Andongrejo Village, District of Tempurejo - Jember. The types of herbs that successfully created are instant or powder medicinal herbs. Some various medicinal herbs were successfully made from simple to complex compound, i.e. instant turmeric, tamarind, ginger, up to for stroks up and cancer solution [15 ].

Strengthening of women's groups in MEE activities were designed as an effort on women's participation in forest resource management. TOGA is commonly found in home garden of a home that running household bussiness [16]. However, women participation is part of gender emancipation, where women are also reserve the right to seek independent economic income.

\section{Development of Recent MEE Site Model}

Site model of MEE showed significant growth towards improvement on forest ecological system. The tress increasingly dense and enlarged, much more cool air condition and sighted animals (e.g. birds, snakes, etc). Some positive impacts for biodiversity conservation in Meru Betiri are described below.

\section{Ecological Improvement}

Ecological results of MEE are medicinal plants (medical) that has been cultivated regularly from Meru Betiri forest getting dense and enlarged, i.e. Kedawung (Parkia roxburghii), Kluwek (Pangium edule), Trembesi (Enterolobium saman), Pule Pandak (Rauwolfia serpentina),
Javanese Chili (Piper retrofractum), and Kemukus (P. cubeba).

For animal species, the rehabilitation zone (particularly in the area of MEE site model) has various fauna such as finches (Pycnonotus aurigaster), nightingale ( $P$. goiavier), orange nightingale ( $P$. bimaculatus), Javanese Munia (Lonchura leucogastroides), jungle fowl (Gallus gallus) and various types of eagle. There are also several kinds of mammals such as deer (Muntiacus muntjac), wild boar (Sus sp.), Pangolin (Manis javanica), long-tailed macaques (Macaca fascicularis) and various types of snakes.

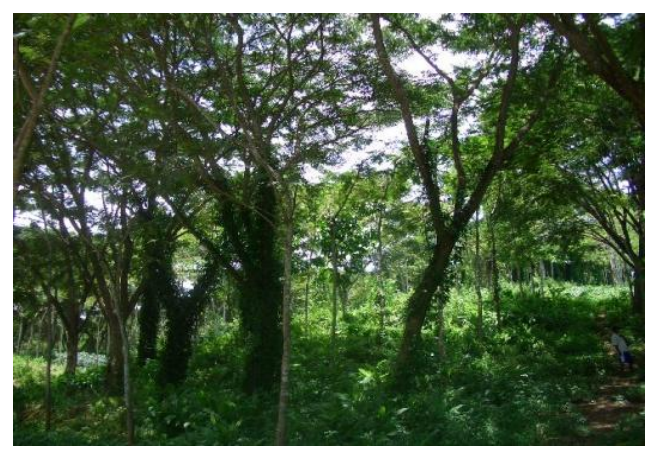

Figure 4. Ecological Condition of MEE Site Model

\section{Educational Improvement}

MEE site model have improved the ecological conditions. KAIL activist published this good condition to public through seminars invitations and other events to make people interest to visit this site model. Numbers of schools surround the forest of Meru Betiri visited MEE site model to see directly morphological diverse of medicinal plants grown. In terms of education, there are three strategies that designed to add community linkages among community, especially students and educator. First strategy is diversification of shade tolerant medicinal plants such as Javanese chili, turmeric, ginger, etc. This model is intended to aware visitors to not only see the primary medicinal plant in the forest but they can also get related knowledge on TOGA plants surround them that have medicinal benefits.

Second strategy is the preparation of conservation educational module. This module was intented to encourage the development of the MEE program on conservation education by distribute conservation module for elementary and secondary schools. The module is made in a participatory manner with the involvement of teachers in school that directly adjacent to the forest. The schools that involved are MI Al-Hikam Langon Ambulu, MTs Bustanul Ulum Curahtakir 
and MTs Addimyati. KAIL expected that future conservation educational module help the students to understand and realized the essential of forest conservation for life. In addition, the presence of the module is expected to emerge conservation cadres who voluntarily maintain the ecosystem of forest resources.

Third strategy is establishment of natural laboratory miniature in school, i.e. built the mini site model in school. The purpose is to introduce types of medicinal plants and their morphology as the miniature of Meru Betiri forest. This miniature was expected to help the teachers clarify their statements about medicinal plants.

\section{Natural Tourism Attraction (Ecotourism)}

MEE site model that have been made got numbers of visit from both inside and outside the area. Teachers from such surround school nearby Meru Betiri visit the site model, while from outside the area is forest farmer groups of Pandegelang, Banten, West Java. Their visitation purposes include outdoor recreation, knowing the characteristics of the tree, supply of fresh air, animals watching, etc. The improvement of ecological conditions in MEE site model provokes community's interest. We expect the MEE site model could be applied also in another barren land that located in rehabilitation zone of Meru Betiri forest area.

The ecological condition of the forest is getting better and interest of community to visit the site model also getting greater. Ecology enchantment of the MEE site model also invite foreign tourist, Dr. Allison from Learning Programme for Islamic School (LAPIS) of the AusAID (Australia). Partnership program were designed together, i.e. introduce the diversity of forest (biodiversity) to students from an early age and develop program for other areas.

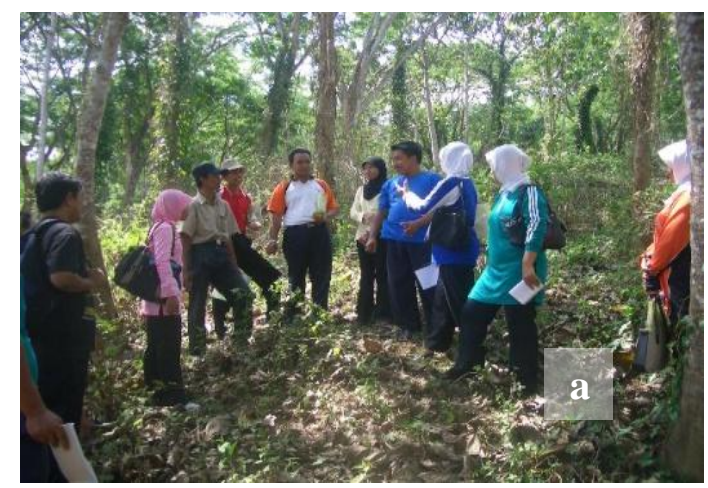

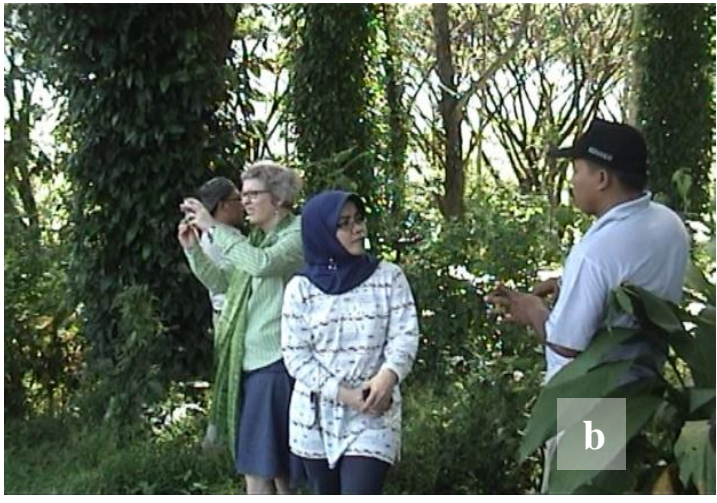

Figure 7. Visitation to MEE Site Model

(a) Science Teacher; (b) Dr. Allison-AusAID

\section{CONCLUSION}

The strategy of community empowerment with MEE (Medical, Education, and Ecotourism) techniques in Meru Betiri forest rehabilitation zone deliver improvement to forest ecology. The success of MEE site model reduces negative perceptions on communities of Meru Betiri buffer forest that said to have less conservation awareness. Assistance to community needs exemplary and tenacity efforts in changing the character of the community to become aware and participate in conserve the biodiversity resources of the forest. The process of forest resources management by involving the community, need to integrate ecological and economic value in achieving optimum results. It means that besides planting the trees, community should be able to take the economy benefits from the forest such as non-timber products (fruits, medicinal palnts, honey bee, etc).

\section{SUGGESTION}

We suggest replicating the MEE site model. The result of the collaboration patterns on conservation efforts between community and forest managers are expected to be input for environmental activists and policy makers to be developed in other areas.

\section{REFERENCES}

[1]. CIFOR. 2012. Forest, food and livelihoods: what policymakers should know. Fact Sheet No. 3 November 2012. http://www.cifor.org /fileadmin/factsheet/RIO+20_Factsheet\%20 -\%20Food\%20and\%20Livelihoods.pdf.

[2]. Hakim, L. 2004. Fundamental Ecotourism. Malang. Bayu Media Publisher. 
[3]. Seegeler, C.J.P., Oyen L.P.A. 2001. Ricinus communis L. Vossen, Umali (Eds.). Plant Resources of South East Asia, 14. Leiden: Backhuys Publishers.

[4]. Rejesus, R.M., Hornbaker R.H. 1999. Economic and environmental evaluation of alternative pollution-reducing nitrogen management practices in central Illinois. Agric. Ecosyst. Environ., 75: 41-53.

[5]. Iskandar, U., A. Nugraha. 2004. Politic of Forest Resources Management: an Issue and Urgent Agenda. Yogyakarta, Debut Press.

[6]. Gunarto, A. 2005. Work Plan of Tenjolaya Agrotourism Area Development in Tapos I Village, Ciampea District, Bogor Regency. Center for Assessment and Application of Agriculture Technology, Deputy of Agriculture Cultural Technology and Agroindustry Biotechnology, Dept. of Assessment and Application of Technology, Jakarta. $38 \mathrm{p}$.

[7]. Zuhud, E.A.M, Ekarelawan, Riswan S. 1994. Indonesian Tropical Forest as Medicinal Plants Resources. Faculty of Forestry, Bogor Agricultural University. Bogor.

[8]. Hadipoentyanti, E., Rostiana O. 1992. Spice Crops Utilization In Indonesia Community Life. Research Institute for Spices and Medicinal Plants. Bogor.

[9]. Gunarto, L., Adachi K., Senboku T. 1999. Isolation and selection of indigenous Azospirillum spp. from a subtropical island, and effect of inoculation on growth of lowland rice under several levels of $\mathrm{N}$ application. Biol. Fertil. Soils, 28: 129-135.

[10]. Mader, R. 2004. Definition Ecotourism. http://www.planeta.com/ecotravel/tour/de finitionZ.html.

[11]. Inskeep, E. 1991. Tourism Planning. An Integrated and Sustainable Development Approach. VNR Tourism and Commercial recreation Series. Van Nostrand Reinhold. New York. 508 p.

[12]. Mujenah. 1993. Community Interaction with Medicinal Herbs in Meru Betiri National Park. Department of Forestry, Faculty of Forestry, Bogor Agricultural University. Bogor.
[13]. Meijaard, E., Abram N., Wells A.J., Pellier A.S., Ancrenaz M., Gaveau D.L.A., Runting R.K., Mengersen K. 2013. People's perception about the importance of forest on Borneo. PLoS ONE 8(9): e73008. doi:10.1371/journal.pone.0073008.

[14]. Boissiere, M., Mulcahy G., Sethaphal L., Beang L.C. 2014. Improving the management of commercial non-timber forest products in Cambodia for the benefit of local communities. Bois et Forets des Tropiques, 67 (317).

[15]. Tukiman. 2004. The Utilization of Family Medicinal Plants (Pemanfaatan Tanaman Obat Keluarga - TOGA) for Family Health. Faculty of Public Health. University of North Sumatera.

[16]. Sumarsono, H.R., Muhibat, Mirna Lei, and Hutapea J.R. 1995. Family Medicinal Plants Taman Obat Keluarga (TOGA). Departement of Health of Indonesia, Directorate of Medicinal Herbs Monitoring, Director General of Medicine and Food, Jakarta, 65 p. 